\title{
Public Policy of Gender Equality in Albania in the Contexts of New Institutionalism
}

\author{
Eglantina Gjermeni ${ }^{1}$, Alkida Lushaj ${ }^{2}$ \\ 'Eglantina Gjermeni, Parliament of Albania, Tirana, Albania, egjermeni@hotmail.com \\ ${ }^{2}$ Alkida Lushaj, OSCE Presence in Albania, Parliament of Albania, Tirana, Albania, kida.lushaj@hotmail.com
}

\begin{abstract}
The core of this paper is to analyze the public policy of gender equality in Albania, particularly on policy areas of political participation, in the context of new institutional approaches. Having done a research, this article attempts to explain the effects of mechanism as gender quota to the level of women's participation in politics and decision-making in Albania. At the same time, examines the challenges of gender quota implementation in Albania. In this paper, it is understood that the interpretation of "the gender inequality problem" determines the equality policies applied on this issue and the structure of formal institutions in that policy. That is, how the gender equality policy has been formed and applied as a public policy in Albania. Besides, equality policies and formal institutional structure on that issue is being formed depending on how "the problem of gender inequality" is perceived by policy-maker actors. In this paper, using the concept of gender as a process analysis, we find evidence that the implementation of gender quotas increased the number of women's participation in politics and decision-making and brought in a more diverse group of women. We also find that women in Albania still continue to face inequality and discrimination, and there is still a lot to be done, to enjoy their rights de facto and to have effective protection against gender discrimination.
\end{abstract}

KEYWORDS: Gender Equality, Gender Quota, Public Policy, New Institutionalism

\section{Introduction}

Gender equality policies have gained importance, especially in recent decades. Grass-roots movements have been a considerable element of this policy establishment process since the 1980s. Due to the recent developments regarding international human rights, the gender equality policies in Albania are also undergoing a transformation phase.

In recent years, at a global level, there has been a noticeable increase in women's participation in public life. However, women's participation in decision-making remains low. Worldwide, women have managed to be part of parliaments at 24 percent (IPU 2018), while in 22 countries they have managed to exceed 30 percent of parliamentary participation. Increasing the number of women in decision-making is an important step towards achieving a society of equal opportunities towards a more democratic and inclusive society.

Ensuring women participation at all decision-making levels could lead to more gender sensitive policies and reforms, which will ensure a better complementarity of the needs of women and men in society. Providing equal opportunities between men and women is an issue of democracy and human rights as well. It is an issue of representation, which guarantees that both man and women are equally represented and that their needs and interests are equally addressed through legislation and policy making. To address gender inequalities in decision making are used several mechanisms, and one of them is gender quota. The gender quota system is one of the strategies applied in some countries including Albania, in order to increase the participation of women in decision-making and politics.

\section{The gender quota system as a tool towards gender equality}

Many international documents such as the Convention on the Elimination of All Forms of Discrimination Against Women (CEDAW 1979), European Convention on Human Rights (ECGR 1996), UN Security Council Resolution 1325 (UN, S/Res/1325 2000) and Sustainable Development Goals (SDGs 2018) pay particular attention to the gender balance in decision making, considering it as a condition for better governance and a more democratic society.

Albania has ratified a number of conventions, treaties and protocols relating to the protection of human rights, such as the Convention on the Elimination of All Forms of Discrimination against Women, the International Covenant on Civil and Political Rights (ICCPR 1966), the International 
Covenant on Economic, Social and Cultural Rights (ICESCR 1966) and the European Convention on Human Rights (EVHR 2010).

Ensuring gender equality it is not only an international commitment and obligation just because Albania has ratified these international documents, but it is also a national obligation because of Albanian legal framework. In this framework, Albania's constitution has provided some guarantees to stop discrimination on the basis of gender. Also, Law No 9970, dated 24.07.2008 "On Gender Equality in Society" (Law No 9970 2008), as well as Law No 10 221, dated 04.02.2010 "On Protection from Discrimination" (Law No 10221 2010) have established a network of institutions for protection against discrimination in general and gender discrimination in particular.

It is important to underline the fact that special measures taken in the context of increasing women's participation in representative bodies and in decision-making as a whole do not pose a positive discrimination but are attempts to establish equality of opportunity and real or substantial representation between men and women (Gjermeni 2005. 4).

Achieving equal participation of women and men in political and public decision-making leads to better and more efficient decision-making and contributes to life quality improvement (Aleanca Gjinore per Zhvillim 2006, 8). Increasing women's participation in decision-making contributes to positive transformative processes for societies because women account for half of the population in Albania, such as changes in laws, policies, services, institutions, and social norms.

To achieve gender equality in politics and decision making are used several mechanisms. One of the mechanisms being used the most is the establishment of a quota system in the electoral system. In Albania, the Law "On Gender Equality in Society" (2008) (Law No 9970 2008), which first established the gender quota as a legal obligation to guarantee the participation of over $30 \%$ of each gender in the legislative, executive and judicial bodies and other public institutions. Also, it is one of the most important laws in this area, which complements the legal framework in the field of gender equality.

This law aims to regulate gender equality fundamental issues in public life, for equal protection and treatment of women and men, for having equal opportunities and possibilities to exercise their rights and also for their participation and support in the development of all areas of social life.

According to Article 15 of the Law on Gender Equality (Law No 9970 2008, 6), equal representation in all legislative, executive and judicial bodies and other public institutions is achieved when:

a) providing representation over 30 percent for each gender, including in their governing bodies;

b) ensuring equal respect for each gender of the competition procedures and criteria when appointing these bodies;

c) ensuring inclusion of over 30 percent of each gender on the list of candidates for elections in local representative bodies;

d) ensuring inclusion of not less than 30 percent of each gender on the list of candidates submitted by the political parties on the proportional system for the elections of the Parliament of the Republic of Albania;

e) ensuring the inclusion of over 30 percent of each gender in the central and local election management bodies.

Related to the law, national quotas is the electoral quota for the legislature, the Assembly, according to which none of the genders (man or women) can be represented by less than $30 \%$.

This measure will be guaranteed by inclusion in the lists of political party candidates for the proportional system, and not less than 30 percent of each gender (Anastasi, Mandro, Shkurti, and Bozo 2012, 94).

While the quota for local election is the obligation to achieve a representation of each gender over 30 percent. This will be accomplished through the legal obligation according to which in the list of candidates for elections in local representative bodies, the involvement of over 30 percent of each gender should be ensured. Such obligation being also sanctioned in the Electoral Code stating that for each electoral area at least 30 percent, of lists with several names, shall belong to each gender (Electoral Code 2016, 81). 
Regarding quota for the electoral bodies, the law on gender equality has considered the legal obligation to guarantee the quota in the electoral bodies, and in all the commissions administering the elections (Anastasi, Mandro, Shkurti, and Bozo 2012, 97).

In Albania, the gender quota serves as a mechanism that has not only increased the responsibility of political parties to involve more women and girls in the elected bodies, but also provides space for the implementation of the national legal framework on gender equality and conventions ratified by Albanian state. Implementation of gender equality law has led to improved gender balance at all gender equality levels, especially in parliament. This is also obvious from percentage in participation statistics in some legislatures.

According to the data released by INSTAT (2017, 107), during the period 1920-1945, the Parliament of Albania was composed only by men. The first women participating in the Parliament were elected in the 1945 legislation. The degree of women's participation in the Parliament of Albania has been virtually constant throughout the 1997, 2001 and 2005 legislatures not exceeding 10 per cent.

During 2001-2005, the largest men's participation in the parliament was 94 per cent. Significant improvement of women's participation in the Parliament of Albania was made possible only after the inclusion of the 30 per cent quota, provided in the electoral code amendments in 2008.

In parliamentary elections in 2009, women's participation in parliament increased by more than twofold, from 7 per cent to 16 per cent. The rising tendency is also noted in the 2013 parliamentary elections, reaching 18 per cent, to 23 per cent in 2015 and to 29, 29 per cent or 41 women deputies from 140 in 2017. As we see from the table number 1, the highest level of women's representation in the Parliament of Albania, since 1992 when the first pluralistic elections were held, is in 2017. This is a great achievement for all the society ensuring more democracy and good governance in Albania.

Table 1. Composition of parliament since 1920 (INSTAT 2017, 110)

\begin{tabular}{|c|c|c|c|c|}
\hline & \multicolumn{2}{|c|}{ Number } & \multicolumn{2}{c|}{ In \% } \\
\hline Year & Men & Women & Men & Women \\
\hline 1920 & 37 & 0 & 100 & 0 \\
\hline 1921 & 78 & 0 & 100 & 0 \\
\hline 1925 & 75 & 0 & 100 & 0 \\
\hline 1928 & 57 & 0 & 100 & 0 \\
\hline 1945 & 76 & 6 & 93 & 7 \\
\hline 1950 & 104 & 17 & 86 & 14 \\
\hline 1958 & 171 & 17 & 91 & 9 \\
\hline 1970 & 192 & 72 & 73 & 27 \\
\hline 1974 & 167 & 83 & 67 & 33 \\
\hline 1982 & 174 & 76 & 70 & 30 \\
\hline 1990 & 169 & 81 & 68 & 20 \\
\hline 1991 & 199 & 51 & 80 & 7 \\
\hline 1997 & 144 & 11 & 93 & 7 \\
\hline 2001 & 131 & 9 & 94 & 16 \\
\hline 2005 & 130 & 10 & 93 & 18 \\
\hline 2009 & 117 & 23 & 84 & 21 \\
\hline 2013 & 115 & 25 & 82 & 23 \\
\hline 2014 & 111 & 29 & 79 & 24 \\
\hline 2015 & 108 & 32 & 77 & 29,29 \\
\hline 2016 & 107 & 33 & 76 & \\
\hline 2017 & 101 & 41 & 72 & \\
\hline
\end{tabular}


Women's increased participation in the Albanian Parliament, has mainly come as a result of the inclusion of $30 \%$ quota in the amendments of electoral code in 2008, as well as by lobbying efforts of women's organizations, civil society, international organizations and women parliamentarians to introduce and implement gender quotas, and due to the greatest awareness of the importance of women's political representation.

According to Law "On Gender Equality in Society", political parties are considered as key subjects to guarantee gender balance in the central and local representative bodies. Pursuant to Law "On Gender Equality in Society", political parties violating the provisions of Article 15 (Anastasi, Mandro, Shkurti, and Bozo 2012, 96), pay a fine of up to one-tenth of the state's fund for financing the election campaign until the correction of the violation.

Political parties shall, as key subjects to guarantee gender equality, be emancipated and democratized to involve more women in decision making, to support and provide them the necessary space to reveal their potential.

\section{Challenges of gender quota implementation in Albania}

Despite legislation improvements, women in Albania continue to face inequality and discrimination only because they are women and there is still a lot to be done, to enjoy their rights de facto and to have effective protection against gender discrimination. Thus women, regarding representation in public and political life, continue to be underrepresented under the $30 \%$ quota provided by the law. Due to the fact that the implementation of gender quota is considered as the beginning of a long-term process of eliminating gender inequalities, in Albania it remains a major challenge for Albanian women, political parties, institutions and civil society.

Establishing gender quotas should not be just a step towards achieving gender equality. At the same time, political parties should pay special attention to the development and implementation of party programs that include gender perspectives in all their aspects, and make gender equality an essential policy goal that they promote. They should also endeavor to undertake initiatives that encourage and nurture women, provide full and equal support to women's logistics and financial affairs.

Unfortunately, women's unequal access to financial resources limits their engagement and leverage in many political activities. Women's exclusion from certain circles of power and moneyed networks, in addition to their own actual economic status - which is documented to be inferior to men - affects their nomination and recruitment as candidates (USAID, NDI Women's Network Equality in Decision-Making 2018. 7).

Political parties in Albania as main subjects that guarantee gender balance do not yet have the right awareness and vision regarding the importance of this issue. Political parties that guarantee gender balance should be emancipated and democratized to involve more women in decision-making and to create more space to show the potentials they have.

It is important that women and girls bring their own experiences and approaches to the decisionmaking processes in the field of their gender role as the main guardian of the family and as a pillar of community development. This involves greater attention to the interests and needs of the family, children and people in need; a greater focus on the decision-making process in the face of a hierarchical and authoritarian decision-making; as well as a tendency to engage with all the actors involved in decision-making (Aleanca Gjinore per Zhvillim 2009, 18).

Also the sanctions foreseen for the political parties, for not enforcing the quota obligation, often in Albania have been weak. Based on the Slovenian legislation model, it would be fairly correct that the lists that do not comply with the quotation projections are declared ineffective (Anastasi, Mandro, Shkurti, and Bozo 2012, 96).

\section{Conclusions}

Increasing women's participation in public life is a key element for the development and democratization of a country. Inclusion of women in all aspects of political life is important not only 
because women account for half of the population in Albania but because achieving balanced participation of women and men in political and public decision making is a necessary condition for the better functioning of a democratic society. The exclusion of women from power worsens public life and promotes the development of an unfair society, which curbs the development of a country in all three aspects: political, economic and social.

Gender quota is considered as a way to continue to gender balance at decision making in all the levels. We have argued that as a result of the inclusion of $30 \%$ of the gender quota, women's participation in parliament increased to 29, 29 per cent in 2017 that is the highest level of women's representation in the Parliament of Albania since 1992 when the first pluralistic elections were held. But despite legislation improvements, women in Albania continue to face inequality and discrimination. Implementation of gender equality law should bring gender balance improvement to all levels or aspects of policy making, and not just in parliament.

To provide the opportunity to women to become influential actors in decision making and to achieve gender equality in Albania, it is important that parties should report regularly on the representation of women at different levels within party structures, including women $/ \mathrm{men}$ membership and to strengthen the sanctions in the electoral code by providing rejection of political parties lists in case when gender quota, for the Albanian Parliament elections, is not applied.

Also of great importance is the awareness of Albanian society and political parties regarding the acceptance and support of women leaders, especially by promoting positive models. Political parties should be emancipated and democratized to involve more women in decision-making and to create more space to show the potentials they have.

Civil society and oversight organizations should lobby the respective state institutions, media and international organizations for the respect of all articles of the electoral code that protect the representation of women.

It is also important to note that achieving gender equality in politics will become a reality when the gender perspective will be included in every aspect of policy making; when needs assessment, drafting of laws, programs and policies, budgeting and the impact assessment of all these political processes would ensure equal consideration and equal addressing of needs, interests and ideas of men and women.

\section{References}

Aleanca Gjinore për Zhvillim. 2009. GAIA 8. Tiranë: Mediaprint. No. 8. IV.

Aleanca Gjinore për Zhvillim. 2006. Përfaqësimi dhe cilësia e demokracisë në Shqipëri - një perspektivë gjinore (Representation and the quality of democracy in Albania - a gender perspective). Tiranë: Pegi.

Anastasi, A., Mandro, A., Shkurti, E., and Bozo, A. 2012. Barazia Gjinore dhe Mosdiskriminimi (Gender Equality and Non-Discrimination). Tiranë: Pegi.

European Convention on Human Rights - Ratified by the Law nr. 8137 / 31.7.1996.

European Convention on Human Rights. 2010. Protocol No. 14. (CETS NO.194). 1 June.

Kodi Zgjedhor i Republikës së Shqipërisë (Electoral Code of Republic of Albania). 2016. Ndryshuar me ligjin nr.74/2012, datë 19.7.2012 dhe ligjin nr. 31/2015, datë 2.4.2015). Tiranë, 81.

Kushtetuta e Republikës së Shqipërisë (Constitution of the Republic of Albania). 1998.

General Assembly of UN. 1966. International Covenant on Civil and Political Rights. Resolution 2200A (XXI). 16 December.

International Covenant on Economic, Social and Cultural Rights. General Assembly resolution 2200A (XXI) of 16 December 1966. 27.

INSTAT. 2017. "Women \& Men in Albania." Instituti i Statistikave. 16.

IPU. 2018. "Women in National Parliaments." World average table situation as of 1 September 2018, http://archive.ipu.org/wmn-e/world.htm.

Law No 9970, dated 24.07.2008. "On Gender Equality in Society."

Law No 10 221, dated 04.02.2010. "On Protection from Discrimination."

Republika e Shqiperise. Kuvendi http://www.parlament.al/RaporteStatistika?statusId=3.

Sustainable Development Goals. 2018. "Goal 5. Achieve gender equality and empower all women and girls.” New York: United Nations, https://sustainabledevelopment.un.org/.

United Nations Development Programme (UNDP) in Albania, Government of Sweden. 2017. Gender Quotas and Women's Substantive Representation in the Local Councils of Albania. Tirana, January.

United Nations. 2000. 1325 Resolution (S/Res/1325). New York. http://www.womenwarpeace.org/toolbox/1325.pdf. 
United Nations, 2010. "Convention on the Elimination of All Forms of Discrimination against Women." 46 Session, CEDAW/CALB/CO/3, 30 July. 2.

UN Women. UNFPA and INSTAT. 2014. Gender Perspectives in Albania. October. 14-19.

UN Albania. UN Women. Albanian Institute for Social Innovation. Pjesemarrja e grave ne politike dhe vendimmarrje ne Shqiperi. Vezhgim mbi perceptimet e publikut 2012-2013 (Participation of women in politics and decision-making in Albania. Survey on public perceptions 2012-2013).

USAID. NDI. Women's Network Equality in Decision-Making. 2018. Women, Money and Politics - A Study of Women Candidates' Access to Political Finance during the 2017 Parliamentary Electoral Campaign in Albania. Tirane. 7. 